
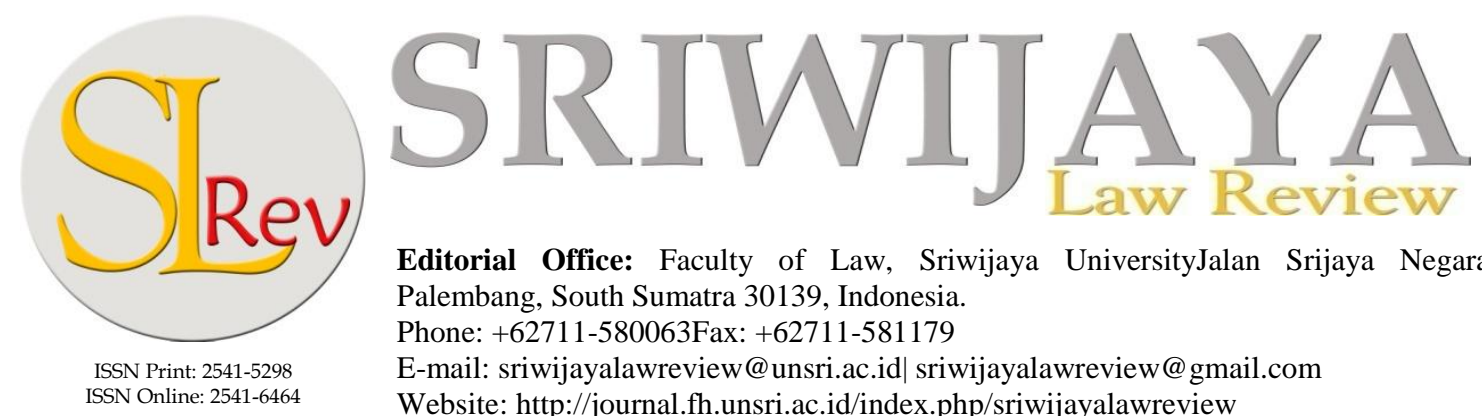

Editorial Office: Faculty of Law, Sriwijaya UniversityJalan Srijaya Negara, Palembang, South Sumatra 30139, Indonesia. Phone: +62711-580063Fax: +62711-581179

E-mail: sriwijayalawreview@unsri.ac.id|sriwijayalawreview@gmail.com Website: http://journal.fh.unsri.ac.id/index.php/sriwijayalawreview

\title{
Legal Status of Credit Bank Guarantee in Indonesia's Legal Guarantee
}

\author{
Erma Defiana Putriyanti ${ }^{1}$
}

\begin{abstract}
The aim of this research is to analyze about the legal status of the letter hiring as collateral for bank loans in the Indonesian security law. The method of this research is a normative juridical. The results of this research indicate that the decree hiring is not included in the objects that can be bound by pledge, fiduciary, and mortgage then hiring decree hiring is not included in the personal guarantee and corporate guarantee. Although the hiring decree is issued by a legitimate institution, the institution is not bound by an agreement between the debtor debts with the bank but when the decree was used as security for the bank. Hiring letter is not also included in the general collateral. Decree hiring is not an object and does not qualify as material that can be used as general collateral. The conclusion of this research is that the position of the decree hiring as collateral for bank loans is a new form of guarantee which is not included in the general guarantees and the specific ones. This shows that the system of legal guarantees in Indonesia is not pure anymore embrace a closed system, but has started shifting into an open system.
\end{abstract}

Keywords: Legal Standing of The decree Hiring, Guarantee; Bank Loan.

\section{ARTICLE HISTORY :}

Received: Dec 29, 2016;

Reviewed: April 8, 2017;

Accepted: June 16, 2017;

Published: July 31, 2017.

1 Faculty of Law, The National University, Jakarta, Indonesia

E-mail: erma.defiana@civitas.unas.ac.id

\section{INTRODUCTION}

The source of funding of the banking sector is still the paramount destination for people seeking a loan in Indonesia today. The source of funding of the banking sector gained by the community can be in the form of conventional bank loans or in the form of financing provided by Islamic banks. Although there are other financing institutions such as finance companies, venture capital companies, as well as infrastructure financing but such financing has not been too familiar used by the community. In general, peoples require collateral to obtain credit facilities from banks and Islamic finance. The function of guarantee is as an enabler of confidence in the bank as a creditor that the debtor will fulfill its obligation to pay the debt. In practice, a guarantee which is used by the client is specific guarantees in the form of collateral material such as (1) a pledge, (2) a mortgage rights, (3) fiduciary, and (4) mortgages for ship, and 
personal guarantees, such as personal guarantee and corporate guarantee.

Besides the two forms of guarantees that have been specified in the Act, in practice in the banking sector today, also known as collateral in the form of Decree (SK) appointment as the employees, includes employees who work in government Institution (Civil Servants) and employees who work on private enterprise. SK hiring a decree issued by the institution/ company which explained that one of the names listed employee in that institution or company, received salary/ earnings due to his work and role. Some banks receive SK hiring as assurances from debtors in the form of pensions SK.

SK debt security with hiring a new guarantee object usage practices that developed in the community and is unknown to the security law in Indonesia. In addition, there has been no regulations governing bank SK as collateral in the form of legislation that is binding. Given the regulatory system security law in Indonesia adheres to a closed system (closed system), then the question arises whether the guarantee with this decree can be called a new form of collateral other than those specified by law or not. Furthermore, how the legal position in the guarantee itself. Through rationale, the authors tried to assess and contribute ideas through this research.

\section{Issue}

Based on the above discussion, the issue raised in this research will be how the legal position of Decree hiring (SK) for credit bank guarantee in Indonesia's legal guarantee?

\section{Objectives}

The aim of this study is to know how to legal position the Decree (SK) hiring in Indonesia's legal guarantee.

Benefits The study is expected to add knowledge for academics, practitioners, and society in general regarding the law guarantees, particularly in the banking sector.

\section{Method}

This study is a descriptive analysis, and method used in this study is normative. Normative juridical method is the method which is based on the research literature in the form of assessment and processing of secondary data that include legislation, books, case law and other relevant articles. The data in this study would be compiled and analyzed using qualitative methods. The function of qualitative method to collection and selection data from secondary data and results will be obtained answers to the problems then explain in the form of descriptive qualitative description, which is a describes the problems and solutions clearly and completely based on data obtained from the study.

\section{ANALYSIS AND DICUSSION}

\section{Overview Credit Bank}

\section{Definition credit}

According the provisions of Article 1 (2) of Act 10 of 1998 about Banking, explained that the bank is a business entity that collects funds from the public in the form of savings and distribution them in the form of credit and/or other 
forms in order to increase the standard of living of the people. Based on these provisions we know that the function of a bank is an institution that raise and distribute funds to the community. Distribution of funds to communities through credit can be performed by conventional banks and in Islamic financing when carried out by Islamic banks and Islamic business units.

Etymologically, the credit comes from the word "credere" ${ }^{1}$, which means trust. In other words, Customers who obtain credit from banks are clients who have the trust from the bank. Credit can interpreted as a loan where the repayment is done in installments allowed by the bank or other entity. Based the legislation definition of credit is the provision of money/bills can be equated with that based on the agreement between bank lending with another party that requires the borrower to repay the debt after a certain period of time with interest. ${ }^{2}$

\section{Regulation Law of Credit}

1. Law No. 10 of 1998 on the Amendment of Act No. 7 of 1992 on banking;

2. Bank Indonesia Regulation (PBI) No. 7/3/PBI/2005 regarding Legal Lending Limit for Commercial Banks;

3. Bank Indonesia Regulation (PBI) No. 7/2/PBI/2005 concerning Asset Quality Rating for Commercial Banks;

4. Bank Indonesia Regulation (PBI) No. 7/8/PBI/2005 concerning Debtor Information System; and

1 Rachmadi Usman, Aspek-aspek Hukum Perbankan di Indonesia, Cet. II, (Jakarta: PT.Gramedia Pustaka Utama, 2003), p236.

2 Article $1^{\text {st }}$ Paragraph 11 Act No. 10 of 1998 Concerning Amendment of Law Number 7 of 1992 on Banking.
5. Director of the Bank Indonesia Decree No. 27/162/KEP/DIR dated March 31, 1995 concerning Commercial Bank Obligations to have and Implement Credit Policy Bank.

\section{Principles of Credit}

Before distribution fund such as credit, a bank must believe that the debtor will be able to repay the debt. In order to obtain assurance, the bank will conduct an assessment of the prospective debtors regarding (1) Character/character, (2) Capacity/ability to pay, (3) Capital, (4) Collateral/guarantee, and (5) Condition of Economy/economic conditions. The assessment is known as the principle of $5 \mathrm{C}^{3}$.

1. Assessment of the character (character): Assessment of the character or personality of a credit applicant to determine the honesty and good faith debtor to pay or repay the loans. It can be obtained based on the relationship between the bank and the candidate debtor or information from others who know the moral, personality and behavior of debtor in daily activities.

2. Assessment ability (capacity): Banks must examine the debtor in their business and managerial skills, so the banks believe that the business will be finance is managed by the right people, so prospective borrower is able to repay the loan.

3. Assessment of capital (capital): Banks should conduct an analysis of the

Tika Andarasni Parwitasari, Surat Keputusan Pengangkatan Pegawai Sebagai Jaminan Kredit di Bank, http://p3m.sinus.ac.id/jurnal/index.php/ejurnal_SINUS, accessed on $1^{\text {st }}$ June 2016 , p54. 
overall financial in the past and the future, so bank can know the ability of capital from candidate debtor to support project financing or business theyare concerned.

4. Assessment of the collateral (collateral): Candidate debtor is needed to provide collateral which have high quality and easy redeemably a minimum value of the amount of the credit or financing given to him, it is to bear in the event of bad loans.

5. Assessment of the debtor's business prospects (condition of economy): Banks should analyze the market situation inside and outside the country either past or future, so the prospect of the project or effort candidate debtor financed bank can be predict.

\section{Types of Credit ${ }^{4}$}

1. According to its purpose, the credit can be divided into (1) Working capital and (2) investment credit;

2. According to the funds provided, the credit can be divided into (1) noncash loan and cash loan;

3. According to the number of credits, divided into (1) corporate loans and (2) of retail loans;

4. According to its users, the credit can be divided into (1) consumer credit, (2) productive credit, and (3) the credit profession;

5. According (to) way of withdrawal, the credit can be divided into (1) a conventional credit and (2) of the loan using a credit card;

6. According to the time period, the credit can be divided into (1) short-

Arus Akbar Silondae dan Wirawan B. Ilyas, 2013, Pokok-pokok Hukum Bisnis, Jakarta, Salemba Empat, pp74-75. term loans, (2) medium-term credit, and (3) long-term credit;

7. According to the collateral/guarantee, the credit can be divided into (1) credit to general guarantee under Article 1131 of the Civil Code, (2) loans with special guarantees, and (3) a credit with collateral in the form of deposits.

\section{Rights and Obligations under the Credit Agreement $^{5}$}

Rights and obligations of the parties to the credit agreement are as follows:

1. Rights of the debtor

a. The right to receive loans

b. The right to receive collateral back after payment of the loan is paid off

2. The obligation of the debtor

a. The obligation to pay off the loan on time as agreed.

b. The obligation to submit to the bank letters of the original proof of ownership of collateral

c. The obligation to administer the orderly and correct bookkeeping.

d. The obligation to account or credit insured and soul to the insurance company or credit/soul who has been appointed by the bank

e. The obligation to submit quarterly and annual reports of the debtor company to the bank/lender, the financial statements must be prepared by a registered bank accountant.

3. The right of creditors

a. The right to earn interest.

5 Jatmiko Winarno, "SK Pegawai Negeri Sebagai Jaminan Kredit di Bank", Jurnal Karya Pendidikan, Vol.1 $1^{\text {st }}$. No. $2^{\text {nd }}$ June 2013, p5. 
b. The right to set off or compensation.

c. The right to conduct inspections and supervision of the debtor data relating to loans the lender.

d. The right to sell all warranties with respect to this loan in the future if a breach occurs (default).

e. The right to obtain repayment on time as agreed.

4. Liability creditors

a. The obligation to maintain collateral/guarantee

b. The obligation to secrecy

c. Review of the Law Concerning Security in Indonesia

\section{Definitions and legal principles guarantee}

Assurance also known as collateral and thisneeded to obtain credit from bank. Function of assurance as guarantee to bank that candidate debtor capable to pay their debts. Legal guaranteemanages of legal relationship between creditor and debtor of the guarantee in relation to the imposition of a guarantee to obtain credit $^{6}$. Based on that statement, it can be elaborated on the elements of assurance law, such as: (1) the existence of the rule of law, (2) the collateral creditor and debtor, (3) the existence of collateral, and (4) their credit facilities. Creditor should be making the imposition agreement guarantees. The imposition agreement guarantees accesoir which follows the principal agreement, the credit agreement.

There are some principles in the legal guarantees, as below:

6 Salim HS, 2005, Perkembangan Hukum Jaminan di Indonesia, Jakarta: PT. Raja Grafindo, p6.
1. The principle of publicity which provided that all the rights in the collateral material, except lien must be registered;

2. The principle of specialization;

3. The principle cannot be divided;

4. Principle inbezittstelling the pledge; and

5. The principle of horizontal separation between the ground and the objects attached above the ground.

\section{Sources of legal guarantee}

Guaranteesbe regulated in various regulations, such as:

1. Book II from book of the Law of Civil Law (Civil Code), which regulates the pledge, which began in 1150-Article Article 1161. In addition, there is a setting on the Mortgage, the Civil Code Article 1162 to 1232 ;

2. Books I and II from book of the Code of Commercial Law (Commercial code). In KUHD regulates the mortgage on the ship contained in Article 314-316;

3. Law No. 4 of 1996 on Mortgage;

4. Law No. 42 of 1999 on Fiduciary;

5. Article 51 and Article 57 of Law No. 5 of 1960 on the norm of the Basic Agrarian; and

6. Article 42 of Law No. 21 of 1992 on the voyage.

There are two systems of regulation in the guarantee law. Firstly, closed and opened systems. Indonesia uses closed system in the guarantee law. A closed system is not allowed using a new guarantee except determined by law. In 
the other side, the opened system adopted in contract law.

\section{Type of Guarantee}

According Indonesia'sguarantees law there are two types of guarantee, first general guarantees and the other is specific guarantees. Specificguarantee classifications into two types, there arematerial guarantees and personal guarantee and will explain as below:

1. General Guarantee, that guarantee is based on Article 1131 and Article 1132 book of the law of Civil Law (Civil Code). In general any material that debtors both existing and will exist is a guarantee of repayment of debt the debtor. All assets of the debtor become guarantee with other creditors. Revenue from sales of these objects is divided according to the size of the individual credit, unless there is reason to take precedence $^{7}$.

2. Specific guarantee. Inspecific guarantees there are twokinds:

a. Material guarantee is guarantees haveabsolute right an object which has characteristics direct bearing on certain objects, can be maintained against anyone, always follow the object, and can be transferred ${ }^{8}$. Collateral material divided into four types,(1) mortgages, (2) a security interest, (3) the fiduciary security, and (4)

Refers to Articles 1131-1132 Book of the Law of Civil Law.

8 Note 6, pp46-47. a mortgage on a ship that weighs more than $20 \mathrm{~m}^{3^{9}}$.

b. Personal guarantee is guarantees which direct relationship to the particular individual, can only be defended against a particular debtor of the assets of the debtor. Individual guarantee divided into four, namely (1) the guarantor (borg), (2) bear responsibility/joint liability, (3) as a result of joint liability passive, and (4) the guarantee agreement. In practice there are another type ofpersonal guarantee (1) borgtoch (individual guarantee) and (2) corporate guarantee. Individual guarantee is a guarantee given by a third party on an individual basis, while corporate guarantee is a guarantee given by a business entity incorporated.

c. System Regulationin Law guarantee

System regulations in the law guarantees divide 2 type.There are closed system and open systems. In closed system people are not allowed usinga new guarantee except determined by law. In oppositeopen system allow people to usinga new guarantee other than those specified by law. Indonesia's applied closed system in law guarantees.

\section{Definition and Function of Decree (SK) Hiring}

Based on Law No. 51 Year 2009 regarding the Second Amendment to Law Number 5 of 1986 concerning the State

\footnotetext{
Refers to Sri Soedewi Masjhoen, 1985, Hukum Jaminan di Indonesia, Jakarta: BPHN Departemen Kehakiman RI, p45.
} 
Administrative Court, explain that the Decree (SK) is an administrative decision. An administrative decision is a determination issued by institution or administrative official which contain action of administrative law country based on the legislation in force, which is concrete, individual and final, which inflict legal consequences for the person or entity civil law ${ }^{10}$. Based on these definitions, SK is a decision of the State administration that is both (1) the individual, (2) concrete and (3) final, which means that the SK is not generally accepted, however, only applies to the person named in the decree. Besides the objects contained in the decree are not abstract but tangible, specific and can be determined. Furthermore, when it is published or issued and signed by institution that issued the decree, the decree has been definitively and lead to legal consequences.

SK hiring is decrees stating that the name listed in the letter is employee, work, receive income, and has a certain positions ininstitution/company that issued the decree. Therefore, SK is a legal basis that an employee's work, occupying certain positions, and eligible to receive salary in place where institution issued the decree.The other function SK as an administrative document is as a collection right to receive pensions for civil servants. For private sector employees, SK also serves as a collection right to receive severance funds when entering full duty. Therefore SK has a important position for an employee. In fact, there is

10 Article $1^{\text {st }}$ Paragraph 9 Act No. 5 of 1986 Concerning The State Administrative Court. a presumption that the decree is a "magic letters" because its function can show the status of a person and can determine one's position in the job.

Starting on the important function of SK for employee the todays in banking practice SK can be used as guarantee to the Bank. Even though not all banks are accept SK as guarantee because each bank havedifferent a policy, in practice using SK as guarantee for bank debt are enthused by customers. Bank as the creditor also simplify the requirements and procedures to obtain a loan with SK as guarantee compared with specific guarantee such as fiduciary, deed of mortgage, and the mortgage, SK as guarantee is easier and uncomplicated. Normally banks only requested letters from the institution where employees work to make payroll deductions. Where salaries are deducted used as installment payments each month.

Function Decree (SK) in the credit agreement is as an additional guarantee provided by the debtor, in this case the employee to the bank as a creditor. In bank perspective granting this decree by the debtor to provide assurance that the debtor is able to pay his debts to the bank, because (1) the debtor is a permanent employee who works at institution/company that issued the decree, (2) the debtor has a steady income legitimate job the, (3) indirectly institution/company that issued the decree was bound for help ensure the correctness of the contents of the decree. Assurance and recognition meant to give confidence to the bank that the employee is able to pay off the debt. 
Legal position of Decree (SK) Hiring in Indonesia law guarantee

In this section, the authors will analyze the position SK in a special guarantee, the SK position in collateral material and SK positions in personal guarantees, as well as the position of SK in general guarantee. The position is based on a decree functions which described in the previous section. To be clearer, the authors will describe the analysis of the following authors:

\section{Legal Position of Decree (SK) in collateral material}

\section{Decree (SK) seen as proof of the acquisition salary}

One of the functions of Decree (SK) is a letter indicating that their owners get the salary/ fixed income and legitimate. In Law Material, the salary can be classified as an Material (zaak), i.e. moving objects intangible (immaterial). Material is every object and every right that can be controlled by proprietary rights ${ }^{11}$. Under the provisions of Article 499 of the Civil Code, it is known that materials can be divided into two: the material in the form of goods and materials in the form of rights. Salary includes materials into a right, because the salary is the right to claim (receivable) an employee of the institution/ company where he worked. The element definitions in subsequent material is the material can be controlled by proprietary rights. A property right is the right to enjoy the usefulness of something material freely and act freely against the material with full sovereignty, insofar as not contrary to law, public

11 Article 499 of the Civil Code. order, and does not interfere with the rights of others ${ }^{12}$. Then, anything considered as objects if it can be controlled by the propertyrights. Salary is a right receivable/accounts that can be controlled by property rights, which are owned by employees as remuneration/compensation for work already done.

The next discussion is a position salary as a moving material. A moving material is a moving material due to its nature as well as legislation. Salary includes moving objects because of its own if it can move or be moved. ${ }^{13}$ It called a moving material because the laws when the materialclassified as moving materials by the law ${ }^{14}$, such as stocks and bonds. Salary classified as a moving object as it can be transferred. Furthermore, salaries are classified as immaterial because of its form that cannot be touched by the human senses.

Based on the above description, we can identify that salary is an immaterial object because salary determined by a decree. However, in a bank credit agreement, SK becomes collateral not a salary. SK cannot be categorized as an object, even though legally an employee whose name is listed in the decree has employment rights, including to a salary. Bank may accept SK as collateral because decree contained the legal certainty that the client (in this case the employee) has the rights guaranteed by the legislation. One of the rights is a salary, where the salary is a tool to pay off the debt to the bank.

\footnotetext{
Refer to Article 570 of the Civil Code. Refer to Article 509 of the Civil Code. Refer to Artice 511 of the Civil Code.
} 


\section{Position SK in a special guarantee material}

Specific guarantees are special rights on specific guarantees to holders of lien, mortgage, deed of mortgage, and fiduciary. In a special guarantee, objects that have economic value became object of the guarantee.

1. SK cannot be bound by pledge

Lien is creditor obtain right on a moving goods handed over by the debtor as collateral for debt and authorized the creditors to take repayment of debt of goods precedes it with other creditors ${ }^{15}$. According definition of the lien, we can know that the objects that made the object of pledge must be submitted to the pledger (principle inbezittstelling) and under the authority of the recipient pawn. Salary legitimate in the decree cannot be controlled by the recipient pawn. De facto, SK as a collateral held by the bank, but the bank cannot execute the decree (sell/ auction) when a debtor defaults, as generally principles in the pledge. Although the bank has a payroll deduction authorization letter from agencies/ companies that issued the decree, but the letter also cannot be controlled by the bank. This is caused by these letters cannot be executed by the bank, either sold or auctioned. The letters were only as reassurance and proof that the employee has the right to claim for wages and salaries. While in pawn, goods which become the object of an executable (sold or

15 Refers to Article 1150 of the Civil Code. auctioned) by recipients pledge if the pledger defaults. It can be concluded SK recruitment cannot be bound by the pledge.

2. SK cannot be bound by fiduciary

Fiduciary is a right of ownership of object on based on trust with the provision that the object held ownership rights are still in control of the object owner ${ }^{16}$. SK who made the object of collateral in credit agreements are delivered and saved the bank, they are not under control of owner (debtor) as applicable to the fiduciary. Objects are burdened with fiduciary must be registered ${ }^{17}$. Registration does on Fiduciary Office, Ministry of Justice and Human Rights. According Fiduciary Law, salary in the decree cannot be bound in a fiduciary because the original decree as collateral must be submitted to the bank debt. Another reason is object in Fiduciary law must be registeron Office fiduciary.In practice SK as collateral no liability and does not require any registration then decree cannot be bound by a fiduciary.

3. SK cannot be bound by mortgage rights and Mortgages

Mortgage rights are rights guarantees charged on land rights as mention in Agrarian Law, the other objects that are installed on the land for certain debt repayment that gives precedence to the position of certain

\footnotetext{
16 Article $1^{\text {st }}$ Paragraph $1^{\text {st }}$ Act No. 42 of 1999 Concerning Fiduciary.

17 Note 16, Article 11 Paragraph $1^{\text {st }}$.
} 
creditors toother creditors ${ }^{18}$. Mortgage is materials on the objects do not move to take a replacement thereof for the repayment of an agreement ${ }^{19}$. Based on the definition of mortgage rights and mortgage, we known that the object that is charged from both these guarantees is fixed objects/not moving, such as land, apartments, boats weighing $20 \mathrm{~m} 3$. SK is not included in the fixed objects, then SK cannot be bound with mortgage rights and mortgage.

Based on the description that has been said above, the authors conclude that the position of SK from the standpoint of the salary cannot be put into a special guarantee material.

\section{Position of Decree (SK) Hiring in specific guarantees in the form of individual guarantee}

Point of view institution/company which issued a decree, the decree hiring an admission by institution/company that the employee is (1) an employee who works in place, (2) occupying a particular position in place, and (3) are entitled compensation/salary for the job and the position. Recognition by the decree that meansinstitution/company who issued a decree indirectly (1) bound and (2) it ensure the certainty of the truth of the contents contained in the decree. When employee who is named in the decree shall take legal actions relating to the decree, institution/company that issued his decree will also be bound by the legal acts. Although this attachment is done

\footnotetext{
18 Article 1 Paragraph 1 The Act No. 4 of 1996 Concerning Mortgage Right.

19 Article 1162 of the Civil Code.
}

implicitly and indirectly, including in the case at the time of the appointment decree is used as collateral for bank loans. Decree could be used as collateral for a bank because of the decree is to give recognition and the certainty that the employees referred to in the decree is properly working and occupy a certain position in an institution and earn a fixed salary for such work. Another reason is the SK can be used as collateral for bank loans because SK cannot be traded. In author opinion these reasons provide additional confidence to the bank regarding the debtor's ability to repay the debt. Bank belief is reinforced because there are signatures of officials of the agency that issued the decree. The signature is a form of recognition that guarantees the truth of the decree.

Position of the institution/ company which issues a decree such as the responsibility given by the corporate guarantee. The Corporate Guarantee belongs to individual guarantees. Based on opinion of Sri Soedewi Maschoen, individual guarantee is a guarantee that causing a direct relationship to a particular individual, can only be defended against a particular debtor, the debtor wealth. Corporate guarantee can be interpreted as a guarantee given by a legal entity if the debtor defaults. Institution/companies that issued the decree is a legal entity, so when institution/company issued a decree appointment of employees, indirectly these agencies provide recognition and guarantees regarding the employment status of the person whose name is mentioned in the decree. Thus indirectly institution/company also guarantee the payment of an employee's debt 
as the debtor when the decree was used as collateral for bank loans.

The next question is what extent an attachment institution/company issuing SK with debt agreements between bank and employees? Is also bound to repay the installments payment if an employee defaults?

In general individual guarantees are guarantees given by third parties to the debt of the debtor at the time of negligent debtors. In corporate guarantee, the legal entity acting as guarantor shall be bound to pay the debt the debtor in the case of negligent debtors to pay their debts. It means in order to ensure the fulfillment of the achievements of the debtor, the asset / wealth guarantor bound and may be confiscated or auctioned when the debtor defaults. In other words individual guarantees contained in the bonded material, i.e. assets guarantor.

When we relate credit agreement created by the bank and the debtor (employee) with SK as guarantee, in practice there are not involve the institution (legal entity) who issued the decree. Furthermore, the credit agreement is not determined that the legal entity that issued the decree as guarantor for the debt debtors (employees) are concerned. This means the institution (legal entity) who issued the decree cannot be a guarantor debt repayment of employees and there is no entanglement assets of legal entities as a guarantor of debt repayment when the debtor (employee) negligent. Their acknowledgment and guarantee of the decree by the relevant institution was limited to the acknowledgment and guarantee of the contents of the decree issued. That is a guarantee that the debtor is an employee who works and occupies a certain position and salary/fixed income of the institution. SK as guarantee will give truth to the bank that the debtor is able to repay the debt because it has a steady income from his job in an institution. According authors conclude that SK is not included in individual guarantees in the form of corporate guarantees.

\section{Position SK In Public Guarantee}

General guarantee is a guarantee based on Section 1131 and Section 1132 Book of the Law of Civil Law. According to Section 1131 outlines crucial that any material that debtors both existing and will exist in the future, both mobile and fixed a guarantee against debt repayment made. Furthermore, Article 1132 specifies that assets of the debtor as collateral jointly for all creditors who provide debt to him. Proceeds from the sales of these objects are divided according to the size of the accounts receivable balance of which each unless there is a legitimate reason to take precedence.

Based on provisions of Article 1131 of the Civil Code mention above,we can know that the general guarantee is meant here is very broad because it covers all the wealth (material) which is owned by the debtor, ie:

a. Existing material

b. Material that will exist in the future

c. moving objects

d. Immovable objects 
Referring to the previousexplanation that SK employees are not included objects. SK is anevidenceto get salary/ income. In SK there is certainty that the employees concerned have the right personnel, such as salaries. Although, salaries classified as intangible movable objects however the object of guarantee in credit agreements are SK, not a salary. Salaries give confidence and legal certainty to banks as a repayment of debt installment debtors/employee concerned.

Referring to that explanation we can know that the SK is not an object, because it does not qualify as a material that can be used as collateral. Terms material which can be used as general guarantee: (1) economical and (2) it could be transferable rights to another person. SK is economical because it can be valued in money and where there is legal certainty about the rights of employees related to economic value. SK contained proof of the right an employee on salary so that SK can be measured by money. SK cannot transferable to another person in any way, such as a purchase agreement, auction, inheritance, and grants. In accordance with the characteristics ofSK as a letter which is concrete, individual and final. This means that SK applies only to the person whose name is listed in SK. However, the rights contained in SK can be transferred to another person, especially the right to get salary. Based on these descriptions it can be concluded that SK does not qualify to be classed as general collateral as defined in Civil Code Article 1131 and 1132. SK excluding assets in the form of material as defined in Section 1131 of the Civil Code. In this case SK as a letter which has legal certainty to obtain employment rights, including the right material (salary).

\section{SK constitute new guarantee}

There are two types system of legal guarantees, closed system and open system. In closed system people are not allowed to hold the new guarantees other than those specified in the legislation. In opposite open system person can hold any collateral other than those stipulated in the legislation. Indonesia applies close system. However, together with the developments of the community then grow new values were developed in the community. The author argues that the legal arrangements guarantee system in Indonesia is now no longer purely embrace a closed system. However, already shift from a closed system into an open system. This was proven by the appearance of new objects that can be used as collateral for bank loans, for example, SK hiring and copyrights that may be bound by a fiduciary. The emergences of new types of collateral are influenced by the needs of the community. Therefore, the law should follow the dynamics of the society with accommodate new types of collateral through binding regulations.

\section{CONCLUSION}

Decree (SK) Hiring an appointment letter containing the decision of a person named in SK for work, occupying certain positions and receiving income for work and his role at institution that issued SK. SK employees are not included in special guarantees, either in the form of guarantees or collateral material 
individuals. SK cannot be bound by the pledge because SK cannot be sold/auctioned if the debtor defaults as in institution as pledge. SK cannot be bound by the fiduciary because the objects are burdened fiduciary must be registered and the object to remain in authority debtors. While the use of SK in bank credit guarantee must be submitted to the relevant bank and it does not require registration of the decree. SK cannot be bound with mortgage rights and a mortgage, since SK is moving objects, while the objects that can be encumbered with mortgage rights and a mortgage is a fixed object (not moving). SK cannot be bound by an individual guarantee (corporate guarantee). Although SK is guaranteed and recognized by institution/legal entity who issuing SK but legal entity not bound in the credit agreement and it is not bound to pay off debts when the debtor negligent. SK employees are not included in the general collateral as in Article 1131 of the Civil Code. Objects in general guarantee is any kind of material (assets), while SK was not included in the object, the object both material and immaterial objects. Conditions an object can be used as general guarantee is to have economic value and are transferable. SK has economic value but cannot be transfers. According the characteristics SK itself, which is the decision of the State Administrative which is concrete, individual and final. SK is only applicable and binding on the person whose name in SK, so it cannot be transferred to another party, either through treaties or inheritance. Based on the observations, the authors concluded that SK is a new type of guarantee that cannot be classified as a general guarantee and specific guarantees.

\section{Suggestions}

In relation with the closed system adopted in the law guarantees in Indonesia, SK do not qualify for collateral bank loans, because it is not included in the types of collateral that have been specified in the legislation. However, because of the needs of the communityin banking sector, SK can be used as collateral for bank loans. This shows that a closed system is not applied unanimously, but it has been affected by an open system. Law should follow the dynamics of development and the needs of society in order to create order and certainty of the law with justice. Therefore the authors recommendation is binding rules need to be made to the kinds of guarantees that new growth, in order to create legal certainty in the community.

\section{REFERENCES}

\section{Books}

Akbar, Arus dan Ilyas Wirawan. 2013. Pokok-pokok Hukum Bisnis. Jakarta: Salemba Empat.

Djumhana, Muhammad. 2006. "Hukum Perbankan di Indonesia, Bandung: PT Citra Aditya Bakti.

Halim, Rahmadani. 2006. Pelaksanaan Perjanjian Kredit dengan Jaminan Surat Keputusan Pengangkatan Pegawai Negeri Sipil (Studi Penelitian di PT.BRI Persero Cabang Lumajang). Tesis S-2. Semarang: Fakultas Hukum Universitas Diponegoro.

HS, Salim. 2005. Perkembangan Hukum Jaminan di Indonesia. Jakarta: PT. Raja Grafindo. 
Soewarso, I. 2002. Aspek Hukum Jaminan Kredit. Jakarta: Ikatan Bankir Indonesia.

Sofwan, Sri Soedewi Masjchoen. 1985. Hukum Jaminan di Indonesia. Jakarta: BPHN Departemen Kehakiman RI.

Sofwan, Sri Soedewi Masjchoen .1980. Hukum Jaminan di Indonesia Pokokpokok Hukum dan Jaminan Perorangan. Jakarta: BPHN Departemen Kehakiman RI.

Usman, Rachmadi. 2003. Aspek-aspek Hukum Perbankan di Indonesia. Cet. II, Jakarta: PT.Gramedia Pustaka Utama.

\section{Journals}

Parwitasari, Tika Andarasni. Surat Keputusan Pengangkatan Pegawai Sebagai Jaminan Kredit di Bank, eJournal SINUS, http://p3m.sinus.ac.id.

Silsilia, Resu., Zarfinal, dan Suamperi, Pengikatan Surat Keputusan Pegawai Negeri Sipil Sebagai Agunan Dalam Perjanjian Kredit Bank (Studi Kasus Bank Nagari Utama Padang). e-Jurnal Bung Hatta, Vol. 3, No. 1, 2013, (www.ejurnal.bunghatta.ac.id.)

Winarno, Jatmiko, SK Pegawai Sebagai Jaminan Kredit di Bank, Jurnal Karya Pendidikan, Vo. $1^{\text {st }}$, No. $2^{\text {nd }}$ June 2013.

\section{Legislations}

Act No. 10 of 1998 Converning Amendment of Law Number 7 of 1992 on Banking.

Act No. 4 of 1996 Concerning Mortgage Right.

Act No. 42 of 1999 Concerning Fiduciary.

Act No. 5 of 1960 Concerning The Principles of Agrarian Basic Regulation.

Act No. 21 of 1992 Concerning Shipping. Act No. 5 of 1986 Concerning The State Administrative Court.
Act No. 51 of 2009 Concerning the Second Amendment Act No. 5 of 1986 Concerning State Administrative Court.

The Civil Code, Government Gazette 1847 No. 23.

Book of the Law of Commercial Law, Government Gazette 1847 No. 23.

Bank Indonesia Regulation (PBI) No. 7/3 /PBI/2005 regarding Legal Lending Limit for Commercial Banks.

Bank Indonesia Regulation (PBI) No. 7/2 /PBI/2005 concerning Asset Quality Rating for Commercial Banks.

Bank Indonesia Regulation (PBI) No. 7/8 /PBI/2005 concerning Debtor Information System. 